\title{
Translating Health Information Effectively for Latino Populations
}

\author{
Everly Macario, Rebeca Montealegre Boyte \\ California Department of Public Health, Immunization Branch, Richmond, California
}

\begin{abstract}
California is the state with the most Latinos, constituting over one third of California's population. The majority of Latinos, the fastest growing minority group in the United States, does not speak English at home. With lower levels of education, English-language proficiency, and health literacy, Latino people need health information they can understand. Literal translations of materials from English to Spanish without tailoring are common and often result in products containing egregious inaccuracies and awkward language usage that can also be out of context. In a medical setting, these errors can compromise health and be life-threatening. This commentary and tool provides examples of "translations gone wrong" and tips to follow to help make Spanish-language products and interpretation services more culturally and linguistically appropriate.
\end{abstract}

(C) 2008 Californian Journal of Health Promotion. All rights reserved.

Keywords: Latinos, cultural and linguistic appropriateness, health education

\section{Latinos in the United States}

\section{Defining Latino, Hispanic, Mexican, and Chicano in the United States}

Most United States demographic data include the term "Hispanic" under ethnicity or race (even though Latino/Hispanic is an ethnic category in which people can be of any race), but who is a Hispanic and where did this term originate? The term "Hispanic" is a relatively recent one, originating in the Nixon administration when federal employees were tasked with grouping people of mixed Spanish heritage and adding a term to describe such a category to the 1970 U.S. Census questionnaire. By the 1980 Census, "Hispanic" appeared not only on census forms, but also on federal, state, and municipal applications for employment, general assistance, and school enrollment (Fears, August 25, 2003; Fears, October 15, 2003). While the new moniker was embraced throughout the government and quickly became part of the national vocabulary, the term "Hispanic" has not been widely accepted among all persons of Spanish origin.

The often interchangeably used words "Latino" and "Hispanic" can be traced from the original bloodlines of Spanish speakers to populations in disparate parts of the world. Hispanics derive from the mostly white Iberian Peninsula that includes Spain and Portugal, while Latinos descended from the brown indigenous Indians of the Americas south of the United States and in the Caribbean, conquered by Spain centuries ago (Fears, August 25, 2003).

The term "Mexican" refers specifically to those of Mexican descent or those native to the country of Mexico. "Chicano" is thought to have originated as slang that described immigrants and refugees from the Mexican revolution. The term later evolved to define the uprising of Mexican American reformers and rights activists as well as farm laborers and other workers who lived in squalor while toiling for low pay. As activists from other Latin countries joined the movement, "Latino" was adopted as an umbrella term for all groups (Fears, August 25, 2003).

When Hispanics/Latinos/Mexicans/Chicanos are surveyed about how they prefer to be categorized, they most often report wanting to identify with their country of national origin 
(Fears, August 25, 2003). Because "Latino" is typically perceived as more historically and culturally sensitive as well as all-inclusive, this term is gaining popularity by those who identify as either "Hispanic," "Latino," "Mexican," "Chicano," "Argentinean," "Costa Rican," "Puerto Rican," "Cuban," etc.

\section{Growth of the Latino Community}

The Latino community is the largest minority group in the United States and growing. In 2004, it represented an estimated 14.1 percent of the total United States population and accounted for 49 percent of the nation's growth from 2004 to 2005 (U.S. Census Bureau; U.S. Census Bureau News, 2006). California is the state in the country with the largest number of Latinos, comprising more than one third of California's population (Pew Hispanic Center, 2004). In the 1990s, Mexicans constituted more than half of new Latin American immigrants to the United States and comprised 27.6 percent of the total foreign-born United States population in 2000 (Huntington, 2004). In California, the Mexican population will grow 259 percent, and other Latino populations by 254 percent between 2005 and 2050 (Federation for American Immigration Reform, 2006).

Although Latinos are the fastest growing minority group in the United States, the majority (at least 75 percent) does not speak English at home. Therefore when communicating health messages to Latino populations, it is necessary to do so in the language that most use at homeSpanish (Ramirez, 2004). This commentary and tool 1) describes how lower levels of education, English-language proficiency, and health literacy present challenges in creating health education materials and 2) offers consequential steps to improve the development of effective materials targeting Latinos.

\section{Education and Health Literacy}

Health materials and collaterals ideally need to be created in Spanish to effectively reach Latino populations. Special care should also be taken to ensure that the literacy level of the native language used in materials is appropriate (Robert Wood Johnson Foundation, 2005). Compared with the total population in 2000,
Latinos were less likely to have completed high school or college (Ramirez, 2004). In fact, 11 percent of Latinos 25 years of age and older in 2000 had at least a bachelor's degree compared with 28 percent of non-Hispanic whites; of interest, the proportion of the Latino population age 25 and over with at least a bachelor's degree ranged from 7 percent for those of Mexican origin to 23 percent for those of Cuban origin (U.S. Department of Commerce, 2001). Older adults and minority populations, moreover, have the lowest literacy skills (Kirsch, Jungeblut, Jenkins, \& Kolstad, 1993).

Health literacy is defined as the degree to which individuals can obtain, process, and understand basic health information and services needed to make appropriate health decisions. Research on health literacy has consistently demonstrated farreaching consequences for those with low health literacy skills (Robert Wood Johnson Foundation, 2005). People with low health literacy make more medication errors, are less likely to understand insurance coverage rules, and are more likely to fail to comply with treatments, obtain preventive services, or manage their own care effectively. These people are also more likely to be re-hospitalized (Gazmararian, Curran, Parker, Bernhardt, \& DeBuono, 2005).

\section{Need for Culturally and Linguistically Appropriate Information}

With relatively lower levels of education and English-language proficiency often accompanied by low health literacy, many Latinos in this country need health education information they can understand (Robert Wood Johnson Foundation, 2005).

The U.S. Department of Health \& Human Services, Office of Minority Health has outlined federal-level mandates, guidelines, and recommendations with respect to culturally and linguistically appropriate services. One mandated standard states: "Health care organizations must make available easily understood patientrelated materials in the languages of the commonly encountered groups" (Office of Minority Health, 2001). 
For language groups that comprise five percent or more of the state's population, California mandates that state and local agencies must employ a sufficient number of qualified bilingual persons in public contact positions and must provide written translations of materials explaining services offered. California also mandates that any general acute care hospital "must provide language assistance services 24 hours a day for language groups that comprise five percent or more of the facility's geographic service area or actual patient population" (UCSF Center for Health Professions, 2003).

Although federal- and state-level mandates are in place to provide health information in a language Latinos will understand, there are many challenges in making accurate translations that will resonate within the Latino community (Robert Wood Johnson Foundation, 2005). In the following sections, we focus our suggestions on how to improve the linguistic accuracy and cultural appropriateness of health and medical information targeting Latino populations.

\section{Translations Gone Wrong}

It is true, regional variations in language do exist. For example, depending on the Spanishspeaking country, "strawberry" may be translated as "fresa," "fresilla," "fresita," "fresón," or "frutilla;" "beans" as "frijoles," "porotos," "habichuelas," or "judías"; "grapefruit" as "pomelo" or "toronja"; "pork" as "cerdo," "puerco," or "chancho"; "stroke" as "derrame cerebral," "apoplejía," or "accidente cerebrovascular"; and "counselor" as "asesor" or "consejero." However, it is important to note that Spanish is one language, akin to English. Although different accents and idioms are observed among countries whose primary language is the same (e.g., England, South Africa, Canada, New Zealand, Australia, Grenada, Ireland, United States), persons from these countries understand the same "standard," "neutral," or "broadcast" language (whether it is in Spanish or English).

When developing health education materials, it is best to do so in the language of the target audience. For Spanish-speaking Latinos, someone who knows the subject matter and whose "mother tongue" or native language is Spanish is ideal for developing materials. This person should also be sensitive to the audience's literacy level in their own language. Generally, translated texts meant for the public should strive to be written at the third-grade level and never exceed the sixth-grade reading level (Solomon et. al., 2005).

Many Spanish-language materials have been translated from English documents that were originally developed for English-speaking persons by English-speaking persons. Direct and literal one-way translations of print materials from English to Spanish and vice versa (when doing "back translations") without substantial tailoring is common and often results in materials containing egregious inaccuracies as well as awkward language usage that can also be out of context (Solomon, Eberl-Lefko, Michaels, Macario, Tesauro, \& Rowland 2005). In a medical setting, these errors can compromise health and even be life-threatening.

\section{Importance of Getting the Right Meaning Behind the Text}

It is critical that translated materials reflect the correct concepts as intended in original documents. Table 1 shows a few examples of "translations gone wrong" as a result of translating text in literal-rather than conceptual-terms (see Table 1).

\section{"Spanglish" is Not A Language}

Cultural fusion among some less acculturated Latinos has allowed a linguistic phenomenon, "Spanglish," to surface. "Spanglish" involves the conversion of English words into a hybrid English-Spanish language, one that is neither correct in English nor Spanish (see Table 2). As noted above, many times the "Spanglish" word has a different definition in Spanish. Again, these words are not correct in either English or Spanish and if used can result in confusion and lost credibility among the Latino community. 
Table 1.

Examples of "Translations Gone Wrong" Due to Incorrect Literal Translations

\begin{tabular}{|l|l|l|l|}
\hline $\begin{array}{l}\text { English term } \\
\text { or saying }\end{array}$ & $\begin{array}{l}\text { INCORRECT, } \\
\text { literal translation }\end{array}$ & $\begin{array}{l}\text { Possibly } \\
\text { understood } \\
\text { meaning of } \\
\text { incorrect } \\
\text { translation }\end{array}$ & $\begin{array}{l}\text { CORRECT translation of } \\
\text { intended meaning }\end{array}$ \\
\hline $\begin{array}{l}\text { Alcohol } \\
\text { abuse }\end{array}$ & maltrato al alcohol & mistreating alcohol & alcoholismo, abuso del alcohol \\
\hline Food safety & $\begin{array}{l}\text { seguridad de los } \\
\text { alimentos }\end{array}$ & food security & $\begin{array}{l}\text { salubridad de los alimentos } \\
\text { ("healthiness of food") or } \\
\text { higiene alimentaria ("food } \\
\text { hygiene") }\end{array}$ \\
\hline $\begin{array}{l}\text { Medicine, as } \\
\text { in medication } \\
\text { or } \\
\text { prescription }\end{array}$ & medicina & the field of medicine & $\begin{array}{l}\text { remedio, medicamento, } \\
\text { medicación, fármaco }\end{array}$ \\
\hline $\begin{array}{l}\text { To lie on } \\
\text { your } \\
\text { back/stomach }\end{array}$ & $\begin{array}{l}\text { ponerse/acostarse } \\
\text { estómago la espalda/el }\end{array}$ & $\begin{array}{l}\text { to lie with your } \\
\text { mouth facing } \\
\text { upwards/ } \\
\text { downwards }\end{array}$ & $\begin{array}{l}\text { ponerse boca arriba/abajo or } \\
\text { acostarse boca arriba/abajo }\end{array}$ \\
\hline Side effects & efectos al costado & effects to the side & $\begin{array}{l}\text { efectos secundarios } \\
\text { ("secondary effects") }\end{array}$ \\
\hline
\end{tabular}

Source: Authors' personal experience in the field.

Importance of Writing Numbers Correctly: Decimal vs. comma, Celsius v. Fahrenheit When writing prescriptions for medications, physicians and pharmacists need to take special care in making sure Spanish-speaking patients understand the correct quantity of medications they should be taking.

Table 3.

Examples of Countries That Use Commas Instead of Decimal Points and Vice Versa

\begin{tabular}{|l|l|}
$\begin{array}{l}\text { Countries that use a comma where English } \\
\text { writes a point or decimal }\end{array}$ & $\begin{array}{l}\text { Countries that use a point or decimal in the } \\
\text { same manner as the English language }\end{array}$ \\
\hline $\begin{array}{l}\text { Argentina, Bolivia, Brazil, Chile, Colombia, } \\
\text { Costa Rica, Cuba, Ecuador, Paraguay, Spain, }\end{array}$ & $\begin{array}{l}\text { The Dominican Republic, El Salvador, } \\
\text { Guatemala, Honduras, Mexico, Nicaragua, } \\
\text { Uruguay, Venezuela. }\end{array}$ \\
\begin{tabular}{l} 
Panama, Peru, Puerto Rico. \\
\hline
\end{tabular}
\end{tabular}

Source: Authors' personal experience in the field.

This is an especially thorny problem among Spanish-speakers, as some Spanish-speaking countries use a comma, while English-speaking countries use a point. For example, 3.56 (three point five six) in English could be translated into Spanish as 3,56 (tres coma cincuenta y seis) and .07 (point zero seven) in English could be, 07 (coma cero siete) (see Table 3.) Don't forget: 
Spanish-speaking countries use Celsius, not Fahrenheit, when measuring a person's (or the

weather's) temperature. Also, the metric system instead of the English system is used for weight (e.g., kilos instead of pounds), height (meters instead of feet and inches), and other measurements (e.g., milliliters instead of cups).

Table 4.

Examples of Ways Accents Can Change the Meaning of a Word

\begin{tabular}{|l|l|}
\hline Spanish word (with accent, without accent) & Translation \\
\hline ano & anus \\
\hline año & year \\
\hline aun & although, even though \\
\hline aún & still, yet \\
\hline 7 o 2 & can be mistaken for 702 (seven hundred and \\
\hline 7 ó 2 & two) \\
\hline
\end{tabular}

Source: Authors' personal experience in the field.

\section{The Language Divide When It Comes to Health Care}

The language divide between Latinos who are English speakers and those who are primarily Spanish speakers creates obstacles to public health campaigns and medical care (Pew Hispanic Center and Robert Wood Johnson Foundation, 2008). A recent joint Pew Hispanic Center and Robert Wood Johnson Foundation research study (Pew Hispanic Center and Robert Wood Johnson Foundation, 2008) reported the following findings:

- Latinos who are predominantly Spanish speakers are much more likely to lack regular health care than their predominantly Englishspeaking counterparts (32 percent versus 22 percent).

- Seventy-nine percent of Latinos who speak primarily English and three-fourths of those who are bilingual obtained information

\section{Importance of Accents}

Special care must be taken in the placement of accents as they can change the meaning of the same word (see Table 4). 


\section{Tips for "Transcreation"}

In optimal circumstances, a diverse team of native bilingual Spanish-speakers trained in health and medicine would create completely new messages and education products targeted specifically to Latino populations from scratch in-language. However, because of time and budget constraints, this approach is usually unrealistic. When the ideal of creating Spanishlanguage materials from scratch is not possible, we recommend employing a "transcreation" or adaptation process. "Transcreation" involves translation and also the adaptation of format, content, context, tone, and visuals to create resources that resonate and feel natural to Latino populations. We offer the following tips for successful transcreation based on the available literature and our own experiences in the field:

1. Hire native professional translators to translate into their native language (Latino Health Initiative, 2006; Solomon, Eberl-Lefko, Michaels, Macario, Tesauro, \& Rowland, 2005).

2. Never rely on computer translation programs (Latino Health Initiative, 2006).

3. Include a review of translated materials by experts fluent in both languages. Ideally, the team should be composed of individuals with diverse professional titles, as well as representative of different countries of origin. A third set of eyes should also proofread the materials before they go to print (accents and capital letters are often incorrectly placed during the printing process). In Spanish, there are strict rules for how words should be broken down by their syllables when they run from one line to the next. The galley proof stage is a critical time to catch such errors (authors' personal experience in the field).

4. Ask prospective translation services to provide samples of past translations of health education materials, in addition to references from other clients. Ask a native Spanish speaker not affiliated with the agency to review the translations and provide feedback on flow, accuracy, and cultural sensitivity of the translation (see Table 5 for translation resources) (authors' personal experience in the field).
5. Adapt the artistic design of materials to reflect the Latino culture. For example, photographs of family members eating peanut butter and jelly sandwiches may not resonate as readily as their eating rice and beans or an "asado" (a barbecue). Consider the kinds of colors and artwork that would resonate most with Latinos (e.g., yellow and red, indigenous and folk art). Be cautious and sensitive, however, to cultural differences among Latino sub-groups (e.g., Cubans, Mexicans, Puerto Ricans, Salvadorians, Argentineans, Bolivians, Costa Ricans, Venezuelans, Colombians, Peruvians, Ecuadorians, Chileans, Paraguayans, etc.). For example, Mexicans enjoy spicy rice and beans while Argentineans eat beef regularly with only salt added (Latino Health Initiative, 2006; Solomon et. Al.,2005).

6. Pretest materials with members of the target audience. For example, a focus group composed of community-level Latinos could review the translated materials for usefulness, understandability (literacy level), and cultural and linguistic appropriateness (Latino Health Initiative, 2006; Solomon et. Al., 2005). If the health education materials are meant for distribution in a particular geographic area, make sure that the group of Latinos includes natives of the country representative of the majority of Latino people in that region. For instance, testing health education materials in Florida should involve representatives from Cuba (41 percent of Latinos in Florida). In California, testing should include natives from Mexico (84 percent of Latinos in California) and Central America (9 percent of Latinos in California), while in New York testing should include natives from Puerto Rico (33 percent of Latinos in New York) and the Dominican Republic (31 percent of Latinos in New York) (Pew Hispanic Center, 2004).

7. Reach consensus on recommended changes by expert reviewers and target audience members. For example, should "doctor" or "médico" be used for "physician"? Should "seno," "pecho," or "mama" be used for breast in "breast cancer"? Should "Hispanics," "Latinos," "Latin Americans," or "Mexican Amer- 
icans" be used? Should "Estadounidenses" (people from United States) or "Americanos" (Americans) be used? Should curanderos (traditional or folk healers) be mentioned? Should faith or religion be addressed? Should commas be used instead of decimal points when writing numbers (Latino Health Initiative, 2006; Solomon, Eberl-Lefko, Michaels, Macario, Tesauro, \& Rowland, 2005; authors' personal experience in the field)?

8. Request that the translation service maintain an in-house glossary with terminology, phrases, and word choices that are consistent between projects and accurate in representing the targeted audience effectively. Ask the service to share this with you every time there is an update. All reviewers and proofreaders should also have a copy. If you hire a new translator, this piece will facilitate the transition and decrease inconsistencies in future translations (authors' personal experience in the field).

9. Do not use ad-hoc interpreters, untrained staff members, people "off the street," custodians, children, or relatives to interpret. While seemingly easy to resort to, asking family members to interpret for a patient or client is problematic. It may be embarrassing for the patient or client to talk about private health matters with a family member. The patient or client's medical condition and situation may be compromised if he or she does not feel comfortable talking about issues openly (Latino Health Initiative, 2006).

Table 5.

Translation Resources Helpful in Creating Health Information for Latino People

\begin{tabular}{|l|l|}
\hline $\begin{array}{l}\text { Resource } \\
\text { type }\end{array}$ & Citation \\
\hline $\begin{array}{l}\text { Medical } \\
\text { Dictionary }\end{array}$ & $\begin{array}{l}\text { Navarro, F.A. (2000). Diccionario crítico de dudas inglés-español de medicina. } \\
\text { McGraw-Hill/Interamericana de España, S.A.U. Madrid, Spain. }\end{array}$ \\
\hline $\begin{array}{l}\text { Spanish } \\
\text { online } \\
\text { medical } \\
\text { encyclopedia }\end{array}$ & $\begin{array}{l}\text { Medline Plus. Información de Salud para Usted. Un servicio de la Biblioteca Nacional } \\
\text { de Medicina EE.UU. y los Institutos Nacionales de la Salud. } \\
\text { http:/www.nlm.nih.gov/medlineplus/spanish/ency/article/003070.htm }\end{array}$ \\
\hline $\begin{array}{l}\text { Medical } \\
\text { Dictionary }\end{array}$ & $\begin{array}{l}\text { Torres, R. (1995). Diccionario de terminos médicos inglés-español. Gulf Publishing } \\
\text { Company; Houston, Texas. }\end{array}$ \\
\hline $\begin{array}{l}\text { Online } \\
\text { translation } \\
\text { forum }\end{array}$ & $\begin{array}{l}\text { WordReference.com English-Spanish Dictionary. This online discussion forum allows } \\
\text { visitors to arrive at consensus on best ways for translating a specific word or } \\
\text { expression. } \\
\text { http://www.wordreference.com }\end{array}$ \\
\hline
\end{tabular}

Source: Authors' personal experience in the field.

10. Use qualified professional bilingual interpreters. Again, while it may be easy to quickly contact someone onsite who might speak Spanish, this person may be conversant in Spanish but may not know correct medical terminology. A "stranger" might also cause the patient or client to be reticent in revealing what needs to be heard. Translating technical and complex medical and health information into another language is one skill; communicating in the literacy level of the patient/client is another challenge and is best accomplished by trained 
and experienced interpreters ((Latino Health Initiative, 2006; Solomon, et. Al., 2005).

11. Hire interpreters trained in medical terminology. Coach them to not add or omit any information. Interpreters should help patients and clients get correct medical care and services by translating accurately and acting as cultural brokers (Latino Health Initiative, 2006).

12. Use teleconference capabilities (such as three-way calling) so that a patient, his or her health care provider, and the interpreter can converse at the same time, when face-to-face is not possible (Latino Health Initiative, 2006).

\section{Summary}

It is crucial to create health education materials in languages other than English that have been pre-tested for accuracy as well as for correct interpretation to ensure that potential errors do not occur due to miscommunication or misunderstanding. This is particularly true for Spanish-dominant Latinos. Because of the nature of health outreach, misinterpretation of information can result in a number of potentially detrimental consequences, including misdiagnoses, or incorrect or insufficient treatments or preventive measures. When original content cannot be created from scratch, "transcreation" (the adaptation of materials from an original English source) is the ideal alternative. Transcreation goes beyond direct translation and considers the language and culture of targeted populations, as well as may offer cost savings compared to translation from scratch. Hiring native speakers and involving Latino community members at each step of product testing and development will help ensure that Spanish language resources are precise and motivating.

\section{References}

Fears, D. "Latinos or Hispanics? A Debate About Identity," The Washington Post, August 25, 2003.

Fears, D. "The Roots of 'Hispanic'," The Washington Post, October 15, 2003. Federation for American Immigration Reform. California-Projected Population in 2050: Demographic Change. Retrieved April 26, 2007 from http://www.fairus. org/site/PageServer?pagename=research_rese $\underline{\operatorname{arch} 18 \mathrm{ad}}$

Gazmararian, J.A., Curran, J.W., Parker, R.M., Bernhardt, J.M., DeBuono, B.A. (2005). Public Health Literacy in America: An Ethical Imperative. American Journal of Preventive Medicine, 28, 317322.

Hispanics and Health Care in the United States: Access, Information and Knowledge. A Joint Pew Hispanic Center and Robert Wood Johnson Foundation Research Report. August 13, 2008. Written by Gretchen Livingston, Senior Researcher, Susan Minushkin, Deputy Director, Pew Hispanic Center, and D'Vera Cohn, Senior Writer.

Huntington, S. (2004). The Hispanic Challenge. Foreign Policy. Retrieved August 20, 2008 from http://cyber.law.harvard.edu/blogs/gems/culturalagency1/SamuelHuntingtonTheHispanicC.pdf

Kirsch, I.S., Jungeblut, A., Jenkins, 1., Kolstad, A. (1993). Adult Literacy in America: A First Look at the Results of the National Adult Literacy Survey. Washington, DC: National Center for Education Statistics, U.S. Department of Education. Retrieved from http://nces.ed.gov/pubs93/93275.pdf

Latino Health Initiative. July 2006. How To Deal With Latino Data: A Guide for Montgomery County Service Providers. Department of Health and Human Services, Montgomery County, Maryland.

Pew Hispanic Center. March 2004. Latinos in California, Texas, New York, Florida and New Jersey. Retrieved from http://pewhispanic.org/files/factsheets/10.pdf

Ramirez, R.R. (2004). We the People: Hispanics in the United States. Census 2000 Special Reports. Retrieved from www.census.gov/prod/2004pubs/censr-18.pdf

Robert Wood Johnson Foundation (2005). Non-English Materials Issue Brief. Developing better nonEnglish materials: Understanding the limits of translation, Hablamos Juntos. We Speak Together. eUpdate, 2. Retrieved June 11, 2007 from http:// www.hablamos juntos.org/ resource guide_portal/pdf/Brief-NonEngl-Final.pdf 
Solomon, F.M., Eberl-Lefko, A.C., Michaels, M., Macario, E., Tesauro, G., Rowland, J.H. (2005). Development of a linguistically and culturally appropriate booklet for Latino cancer survivors: Lessons learned. Health Promotion Practice, 6, 405-413.

UCSF Center for Health Professions. Health Care Providers' Language Assistance Responsibilities, Major Federal and California Requirements, October 2003. Retrieved from http://www.Future health.ucsf.edu/pdf files/CA_US langasst_reqs1.pdf

U.S. Census Bureau, www.census.gov.

U.S. Census Bureau News. Public Information Office. U.S. Department of Commerce. "Nation's Population One-Third Minority." Press Release May 10, 2006. Washington, D.C.

U.S. Department of Commerce News. "Diversity of the Country's Hispanics Highlighted in U.S. Census Bureau Report." Press Release March 6, 2001. Washington, D.C.

U.S. Department of Health \& Human Services, Office of Minority Health. National Standards for Culturally and Linguistically Appropriate Services in Health Care, March 2001. Washington, DC. Retrieved from http://www.omhrc.gov/assets/pdf/checked/finalreport.pdf

Author Information

Everly Macario, ScD, MS, EdM, Public Health Consultant*

California Department of Public Health,

Immunization Branch, Richmond, California.

5629 S. Dorchester Avenue

Chicago, IL 60637

(773)-752-7732 (Phone)

(509)-752-7738 (Fax)

E-mail: Everly_Macario_ScD97@post.harvard.edu

Rebeca Montealegre Boyte, Latino Health Education

Program Specialist, California Department of Public Health, Immunization Branch, Richmond, California.

850 Marina Bay Parkway, Building P,

Richmond, CA 94804-6403

510-620-3762 (Phone)

510-620-3774 (Fax)

E-mail: Rebeca.Boyte@cdph.ca.gov

or

E-mail: rmboyte@ucdavis.edu

*corresponding author 


\section{Appendix A}

Table 2

Examples of the Incorrect Usage of "Spanglish" Words

\begin{tabular}{|l|l|l|}
\hline English word & $\begin{array}{l}\text { "Spanglish" } \\
\text { (incorrect) word }\end{array}$ & True definition of "Spanglish" word \\
\hline embarrass & embarazar & to become pregnant \\
\hline sensible (practical) & sensible & sensitive \\
\hline preservative & preservativo & condom \\
\hline vacuum & vacunar & to immunize \\
\hline groceries & grosería & rude action or comment \\
\hline carpet & carpeta & ring binder \\
\hline dime & dime & tell me \\
\hline library & librería & book store \\
\hline sale & sale & he/she leaves or dates \\
\hline soda & soda & soda water or coffee bar \\
\hline
\end{tabular}

Source: Authors' personal experience in the field. 